\section{A SABINE'S GULL AT REGINA BEACH, SASKATCHEWAN}

CHRISTOPHER I. G. ADAM, 14 1209 Pasqua St., Regina, Saskatchewan.

The first sighting of the Sabine's Gull at Regina Beach on 28 October, 1979 , by Bob Luterbach and myself is a good example of the teamwork so essential in birding. We had arrived at the Regina Beach Yacht Club shortly after 1100 hours. The weather was cold, windy and overcast. Bob was scanning for birds far out on the lake and, since I couldn't see past him in the car, I decided to check down in front near the shore. A small dark gull suddenly flew in from the west and landed near the docks at the yacht club. It was confirmed as a Sabine's when the wing pattern was observed. The forked, black-banded tail identified the bird as an immature. We left to notify Doug Gilroy but upon our return, the bird had disappeared. Later, about 1300 hours, the gull was spotted in the dock area again, where it remained for some time. The bird was seen on subsequent days, affording good opportunities for photographs. A Bonaparte's Gull was also seen in the yacht club area at the same time.

Godfrey states that the Sabine's Gull is a "rare migrant in the Canadian interior but recorded in Alberta, Saskatchewan, Manitoba, Ontario and Quebec."3 Previous sightings for Saskatchewan are as follows:

(1) 9 June, 1914; Sandy Lake, Churchill River, 3 birds. $^{1}$

(2) 11 June, 1960; Black Bay, Lake Athabasca, 11 birds, 2 specimens taken. ${ }^{6}$

(3) 20 June, 1969; Madge Lake,
Duck Mountain Provincial Park, 1 bird. $^{2}$

(4) 21 Sept., 1969; Prince Albert, 1 imm. ${ }^{5}$

(5) 24 Oct., 1971; Old Wives Lake, 1 bird. ${ }^{4}$

(6) 8-16 Oct., 1977; Saskatoon, Max. of 7 (J. B. Gollop). ${ }^{7}$

'BUCHANAN, A. 1920. Wildlife in Canada. McClelland, Goodchild and Stewart, Toronto. 264 pp. (See P. 224.)

${ }^{2}$ COPLAND, H. W. R. 1969. A Sabine's Gull in southern Saskatchewan. Blue Jay $27(3): 146-7$.

${ }^{3}$ GODFREY, W. E. 1966. The birds of Canada. Nat. Mus. Can. Bull. 203. $428 \mathrm{pp}$.

${ }^{4}$ HOUSTON, C. S. Northern Great Plains (Fall migration, 1971). Am. Birds 26:78-80.

${ }^{5}$ HOUSTON, M. I. 1974. Interesting Prince Albert records by $E$. Derek Beacham. Blue Jay 32(2):110-112.

${ }^{6}$ NERO, R. W. 1963. Birds of the Lake Athabasca region, Saskatchewan. Spec. Publ. 5, Sask. Nat. Hist. Soc. Regina.

'SERR, E. M. 1978. Northern Great Plains (Fall migration, 1977). Am. Birds 32:220-223.

\section{LARGE CLUTCHES OF RING-BILLED GULLS IN MANITOBA}

W. H. KOONZ, Wildlife Research Specialist, Manitoba Dept. of Natural Resources, 1495 St. James Street, Winnipeg, Manitoba.

On 11 June 1979, Bachelor's Island ( $51^{\circ} 45^{\prime} \mathrm{N}, 99^{\circ} 53^{\prime} \mathrm{W}$ ) in Lake Winnipegosis was surveyed for colonial nesting birds. Nests numbered 1,596 Ring-billed Gulls, eight Herring Gulls and 170 Doublecrested Cormorants. 
The Ring-billed Gull colony appeared to contain complete clutches, although no young had yet hatched. Their nests contain "usually hree, sometimes two, very rarely our" eggs." Sixty-two of these Ringbilled Gull nests contained four eggs, eight had five eggs and one had six eggs. The remaining gull nests had the usual three. Numbers of fourand five-egg clutches appear significant because they infer a larger han normal clutch size rather than he pairing of two females.

Other Ring-billed Gull colonies surveyed in 1979 contained abnormal clutch sizes, but none approached the proportion focumented on the Bachelor's Island folony.

HARRISON, COLIN. 1978. A field guide to the nests, eggs and nestlings of North American birds. Collins, New York. 416 pp.

\section{BALD EAGLE NEST IN A MANITOBA HERON COLONY}

W. H. KOONZ, Manitoba Dept. of Natural Resources, 1495 St. James Street, Winnipeg, Manitoba.

On 19 June 1979, while making an herial census of a Great Blue Heron colony on one of Lake Winnipegosis' Sister Islands $\left(52^{\circ} 25^{\prime} \mathrm{N}, 99^{\circ} 46^{\prime} \mathrm{W}\right)$, wo observers and I saw two adult Bald Eagles close to a nest containng two young eagles. The nest was hear the top of the island's largest ree, a dead balsam poplar (Populus palsamifera). I did not see any active peron nests in that tree although here were 30 or more active nests in surrounding trees, some at a disance of $10 \mathrm{~m}$ or less. The eaglets were several weeks old while heron chicks were just beginning to hatch.

The observation is of interest and worthy of future field observation to determine if the two species will coexist in such close proximity. The abandonment of a heron colony at Beaver Lake $\left(54^{\circ} 43^{\prime} \mathrm{N}, 111^{\circ} 53^{\prime} \mathrm{W}\right)$ between 1970 and 1972 supposedly due to the establishment of an eagle nest in the colony was reported by Vermeer (Can. Field Nat. 87:427432).

\section{EAGLE/COYOTE INCIDENT}

SIG JORDHEIM, White Bear, Saskatchewan, SOL 3LO.

On 25 November 1979, I was on a hill overlooking Lake Diefenbaker. At this late date there were still several hundred Canada Geese and Mallard ducks on about an acre of open water toward the south shore of the lake.

I noticed a gathering of eagles on a small island close to the north shore. Through 16X binoculars I noted that one Golden Eagle was feeding on a Canada Goose, and four others were gathered around, hoping to get something for themselves. While they seemed to respect the feeding eagle, they were constantly harassing each other; at one time two of them came to grips and thrashed wildly for a moment until one got free and gave ground.

Then I saw a coyote trotting briskly toward the gathered eagles, coming across the ice from the south side. On getting closer it broke into a lope, then on reaching the island, with head lowered, hackles up and tail swinging from side to side it charged directly at the eagles. 